\title{
Classic Hodgkin Lymphoma - Old Disease, New Directions: An Update on Pathology, Molecular Features and Biological Prognostic Markers
}

\author{
Anamarija M. Perry ${ }^{1}$, Lauren B. Smith ${ }^{1}$, Adam Bagg ${ }^{2}$ \\ ${ }^{1}$ Department of Pathology, University of Michigan, Ann Arbor, MI, USA, ${ }^{2}$ Department of Pathology and Laboratory Medicine, \\ Perelman School of Medicine, University of Pennsylvania, Philadelphia, PA, USA
}

Correspondence: anaperry@med.umich.edu; Tel.: + 734232 5376; Fax.: + 7342325360

Received: 18 January 2021; Accepted: 19 February 2021

\begin{abstract}
The aim of this paper is to review morphologic, immunophenotypic, and molecular features of classic Hodgkin lymphoma, as well as different prognostic markers in this neoplasm. Classic Hodgkin lymphoma (CHL) accounts for 15-25\% of all lymphomas in the Western world. The hallmark of this disease is the neoplastic Hodgkin/Reed-Sternberg (HRS) cell, which is favored to be derived from germinal center B-cells but has lost many of the B-cell markers. HRS cells are scattered within a dense inflammatory infiltrate, and through a network of cytokines and chemokines they shape their microenvironment, evade immune response, survive, and grow. In the last two decades multiple prognostic markers related to HRS cells, the microenvironment or both, have been evaluated in patients with CHL. They include clinical, immunohistochemical, cytogenetic, and molecular markers that can predict survival and identify high-risk patients who will likely relapse after therapy. More recently, circulating tumor DNA analysis by next-generation sequencing has opened new avenues for diagnosis and disease monitoring after therapy. The increased understanding of molecular mechanisms underlying CHL pathogenesis has led to successful implementation of novel therapies, such as anti-PD-1 antibodies, which are becoming a mainstay of treatment in relapsed/refractory patients. Conclusion. Currently, pathologic prognostic markers are not routinely assessed at initial diagnosis of CHL. However, as more therapies become available, it will be important to identify patients with high-risk disease who may benefit from more intense or targeted therapy upfront.
\end{abstract}

Key Words: Classic Hodgkin Lymphoma • Prognostic Markers • Immunohistochemical Markers • Tumor Microenvironment • Epstein-Barr Virus.

\section{Introduction}

Hodgkin lymphoma is a common lymphoma in the Western world accounting for $15-25 \%$ of all lymphomas. This group is comprised of two morphologically and immunophenotypically distinct entities - classic Hodgkin lymphoma (CHL) which accounts for over $90 \%$ of cases and nodular lymphocyte predominant Hodgkin lymphoma $(1,2)$. Although "Hodgkin's disease" was first reported nearly 200 years ago and Hodgkin/ReedSternberg (HRS) cells were described at the turn of the $20^{\text {th }}$ century, the nature of this disease (i.e. neoplastic vs. infectious/inflammatory) remained a mystery for a long time $(3,4)$. The B-cell origin of HRS cells was finally elucidated in the 1990s and the new terminology "Hodgkin lymphoma" was included in the Revised European American Lymphoma (REAL) Classification (5-7). Since then, CHL has been a focus of extensive research which paved the way for better risk stratification and novel therapies.

Classic Hodgkin lymphoma has a bimodal age distribution, with the first peak from 15 to 35 years of and the second after 55 years of age. In resourcepoor countries, however, the first peak occurs earlier in childhood. The overall male-to-female ratio is 1.5:1, but females have higher incidence of nodular sclerosis subtype of CHL $(2,8-10)$. Clini- 
cally, CHL mainly involves lymph nodes, most frequently above the diaphragm with cervical, mediastinal, axillary, and supraclavicular lymph node chains being most commonly affected. In a subset of patients, extranodal tissues are involved, such as spleen, lungs and liver $(2,10)$. Bone marrow involvement is uncommon, occurring in approximately $5 \%$ of patients and is more common in the elderly and HIV positive patients (11). So-called "B-symptoms" such as fever, weight loss and night sweats are seen in $30-40 \%$ of patients (10). Modern therapy of CHL is based on risk stratification with a goal of curing the patient while minimizing acute toxicity and long-term complications, the most feared being malignancy such as acute leukemia and myelodysplastic syndrome (12). Imaging studies, specifically fluorodeoxyglucose positive emission tomography (FDG-PET) is used in staging as well as during treatment to assess response to chemotherapy and plan further treatment (13). For early stage CHL, the standard treatment includes ABVD (doxorubicin, bleomycin, vinblastine, dacarbazine) chemotherapy with or without involved-field radiation therapy. Even though, compared to many lymphomas, CHL has a very good prognosis and high cure rates, $10-30 \%$ of patients will experience relapse and 5-10\% are refractory to initial treatment. The management of these patients is challenging and includes high-dose chemotherapy, autologous stem cell transplant, as well as anti-CD30 antibody brentuximab vedotin, and more recently anti-PD-1 antibodies, such as pembrolizumab and nivolumab (12, 14-16).

The current World Health Organization (WHO) Classification requires integration of all available information - morphology, immunophenotype, genetic, and molecular information, as well as clinical features, in order to properly classify lymphomas. Moreover, additional studies to assess prognostic markers are frequently performed, particularly in non-Hodgkin lymphomas, as they help guide clinicians in choosing the most appropriate course of therapy (2). Prognostic markers in CHL are currently not routinely assessed by pathologists, but as more therapies become available, there will likely be a push to identify patients with more aggressive disease who would benefit from more intense or combined therapy upfront. Prognostic markers in CHL include clinical markers, which differ for early and advanced stage disease. The presence of a bulky mediastinal mass, involvement of multiple nodal sites, extranodal involvement, massive splenic disease, age $\geq 50$ years, and elevated sedimentation rate are predictors of poorer outcome in early stage CHL (17). For advanced disease, the International Prognostic Score (IPS) that incorporates seven clinical variables is used $(18,19)$. The most frequently used pathologic prognostic markers are immunohistochemical markers, due to their wide availability, relatively easy interpretation and low price compared to other methods. Molecular methods used in prognostication most frequently include high-resolution array comparative genomic hybridization $(\mathrm{aCGH})$, gene expression profiling (GEP) and next generation sequencing (NGS). These methods are still not widely available as they require substantial expertise and are relatively expensive. Over the past two decades, numerous studies in the literature have addressed prognostic markers in CHL.

This review will summarize the most relevant pathologically-determined prognostic markers.

\section{Histopathologic Characteristics and Immunophenotype}

Classic Hodgkin lymphoma is histologically characterized by HRS cell and its variants, that usually comprise less than $1 \%$ of cellular infiltrate, scattered in a mixed inflammatory background. Hodgkin/ Reed-Sternberg cell has two or multiple nuclei with open chromatin, accentuated nuclear membrane, and prominent eosinophilic nucleoli. Morphologic variants of HRS cells include mononuclear Hodgkin cells, degenerated mummified cells and lacunar cells, which show shrinkage artifact (i.e. lacunae) in the formalin-fixed tissue. WHO classification recognized four morphologically distinct subtypes of CHL - nodular sclerosis (50-80\% of cases), mixed cellularity (20-30\% of cases), lymphocyte-rich (5\% of cases), and lymphocyte-depleted (1\% of cases). These subtypes are associated with different clini- 
cal presentations and are differently represented among varied age groups $(2,10)$.

Nodular sclerosis CHL, the most common subtype in the Western world, typically presents as a mediastinal mass in young adults. Histologically, lymph nodes show nodular pattern of effacement with cellular nodules surrounded by thick fibrotic bands. The infiltrate is composed of scattered lacunar cells (as well as other HRS variants), which sometimes form clusters and sheets, in a mixed inflammatory background composed of small lymphocytes, plasma cells, histiocytes, eosinophils, and neutrophils (Figure 1A and 1B). Mixed cellularity CHL is more commonly seen in the elderly population, among patients with HIV infection, as well as in the pediatric population in developing countries. Notably, around $75 \%$ of cases are associated with EpsteinBarr virus (EBV). Histologically, lymph node shows diffuse effacement by infiltrate composed of scattered HRS cells in an inflammatory background (Figure 1C and 1D). Lymphocyte-rich subtype is relatively rare and patients frequently present in early clinical stages. Lymph node is effaced in nodular, or less frequently diffuse pattern, and HRS cells are seen in a background composed mainly of small lymphocytes, hence the term "lymphocyte-rich". In the nodular pattern, small/regressed germinal centers are usually seen in the nodules with HRS cells/ variants in the expanded mantle zones (Figure $1 \mathrm{E}$ and $1 \mathrm{~F}$ ). Lymphocyte-depleted subtype, the rarest of all, is associated with aggressive clinical behavior, and often with HIV infection. Histologically, it is characterized by sheets of neoplastic cells, sometimes with prominent fibrosis, with scarce inflammatory cells in the background $(2,20)$.
Table 1. Immunohistochemical Profile of Classic Hodgkin Lymphoma

\begin{tabular}{ll}
\hline Positive markers & Negative or rarely positive markers \\
\hline CD30 & CD19 \\
\hline CD15 & CD79A \\
\hline PAX5 (dim) & PU.1 \\
\hline CD20 & OCT-2 \\
\hline MUM1 & BOB.1 \\
\hline Fascin & CD10 \\
\hline LMO2 & BCL6 \\
\hline HGAL & CD45 \\
\hline CD25 & CD43 \\
\hline Vimentin & EMA \\
\hline- & ALK \\
\hline- & Cytokeratin \\
\hline
\end{tabular}

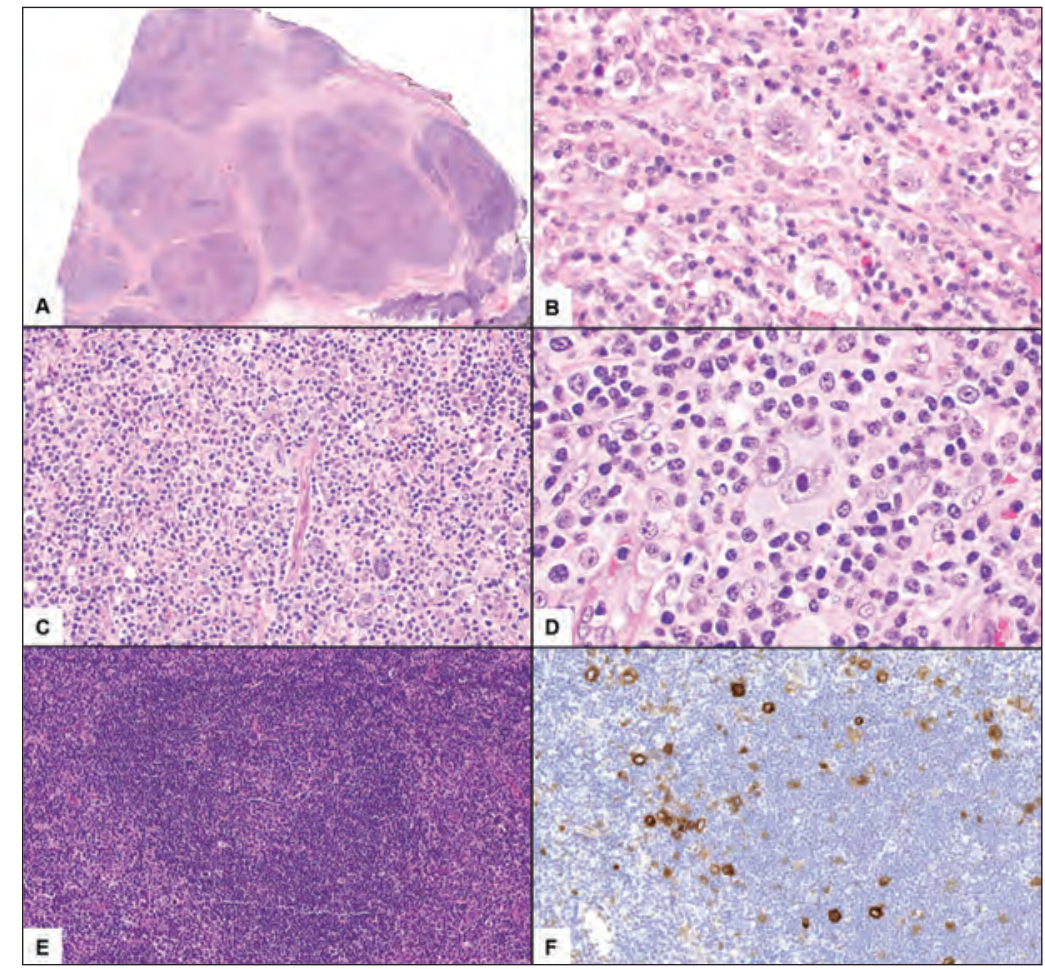

Figure 1. Nodular sclerosis subtype of classic Hodgkin lymphoma showing lymph node effacement by cellular nodules surrounded by thick fibrotic bands (A); infiltrate is composed of scattered lacunar cells in the inflammatory background (B). In mixed cellularity subtype of classic Hodgkin lymphoma there is a diffuse infiltrate composed of scattered RS cells in the inflammatory background (C, D). Lymphocyte-rich subtype of $\mathrm{CHL}$ showing neoplastic nodule composed almost entirely of small lymphocytes (E); CD30 immunohistochemical staining highlights scattered RS cells. (A-H\&E, original magnification $\times 10$; B and D-H\&E, original magnification 400; C-H\&E, original magnification $\times 200$; E-H\&E, original magnification $\times 100$; F-CD30 immunohistochemical stain, original magnification $\times 200$ ). 


\section{Molecular and Cytogenetic Features}

Hodgkin/Reed-Sternberg cells likely originate from germinal center B-cells and show monoclonal immunoglobulin heavy-chain gene rearrangements. In some cases, there is "crippling" somatic hypermutation of this gene that would typically lead to the death of the cell by apoptosis; such cells are rescued by oncogenic mutations and/ or EBV. Another mechanism contributing to the survival of these cells that are otherwise destined to die is the loss of most B-cell surface proteins, as well a B-cell transcription factors PU.1, OCT2 and BOB.1 (5, 7, 29, 34-36). This loss of B-cell phenotype is due to epigenetic silencing of B-cell program regulators, promoter hypermethylation, and upregulation of ID2 and NOTCH1, which are transcriptional antagonists (37-40). Given these unique molecular features of neoplastic HRS cells, including loss of B-cell receptor (BCR) which normally leads to apoptosis in mature B cells, they are dependent on multiple alternate pathways for survival. Major genetic alterations in CHL are summarized in Table 2. Constitutive activation of NF- $\kappa B$ and JAK-STAT signaling pathways are the main genetic features of CHL. Canonical and noncanonical NF- $\kappa$ B pathways are activated through several mechanisms, including mutations in negative regulators (TNFAIP3, NFKBIE, NFKB1A) as well as amplifications, chromosomal gains and structural rearrangements that affect gene loci for MAP3K14, REL, and BCL3 and lead to increased activity (41-46). The JAK-STAT pathway is most commonly activated by amplification of JAK2 gene (9p24.1) and mutations and deletions in negative regulators (SOCS1 and PTPN11). Activation leads to increased phosphorylation of STATs, including STAT3, STAT5 and STAT6 and increased transcription of downstream targets (47-52). Other important deregulated pathways in CHL include NOTCH and PI3K-AKT (53). More recent genomic studies showed that cases of refractory CHL show TP53 mutations, as well as mutations of epigenetic regulators EP300 and CREBBP (54-56).
Table 2. Major Genetic Alterations in Classic Hodgkin Lymphoma

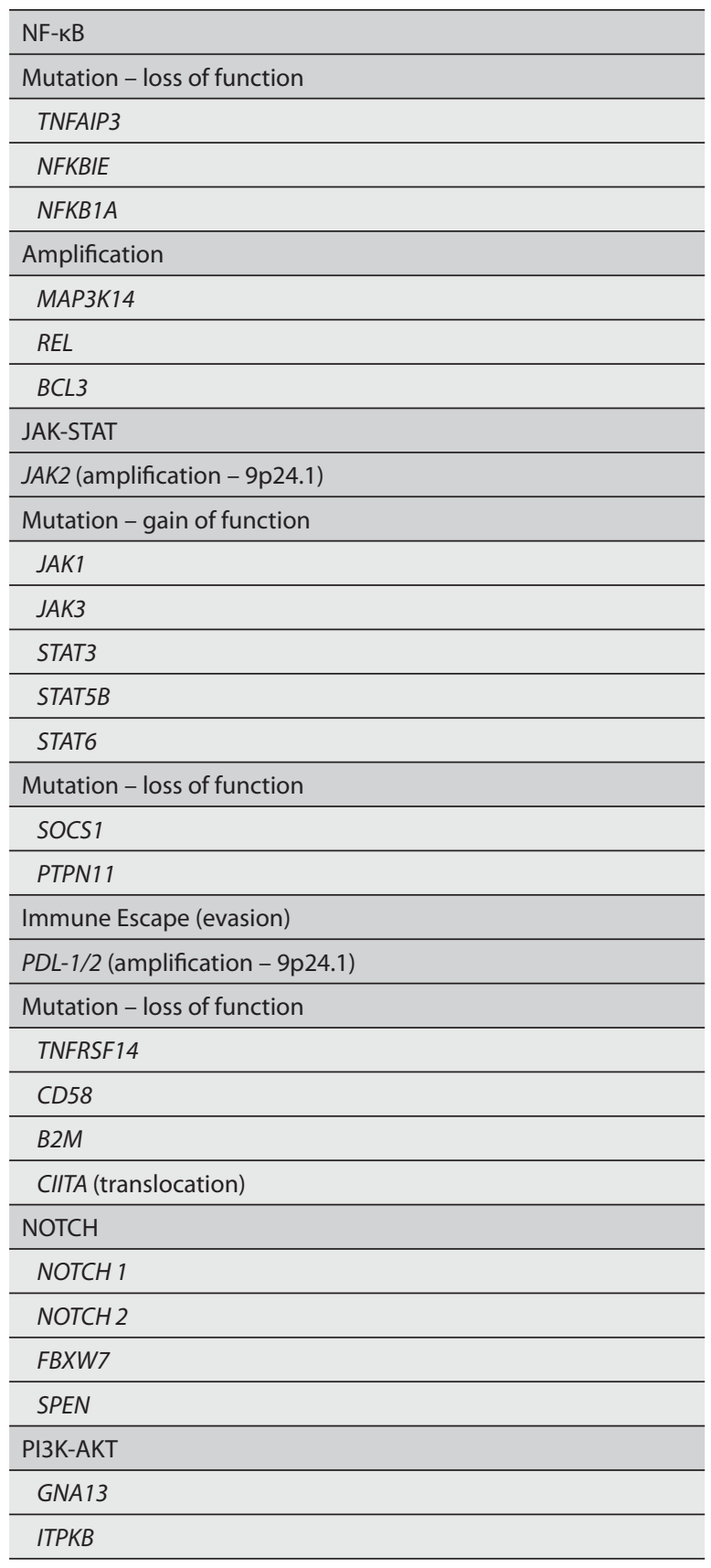

\section{Tumor Microenvironment and Immune Evasion by Reed-Sternberg Cells}

Malignant HRS cells are embedded in a dense reactive microenvironment composed of lymphocytes, plasma cells, macrophages, eosinophils, 


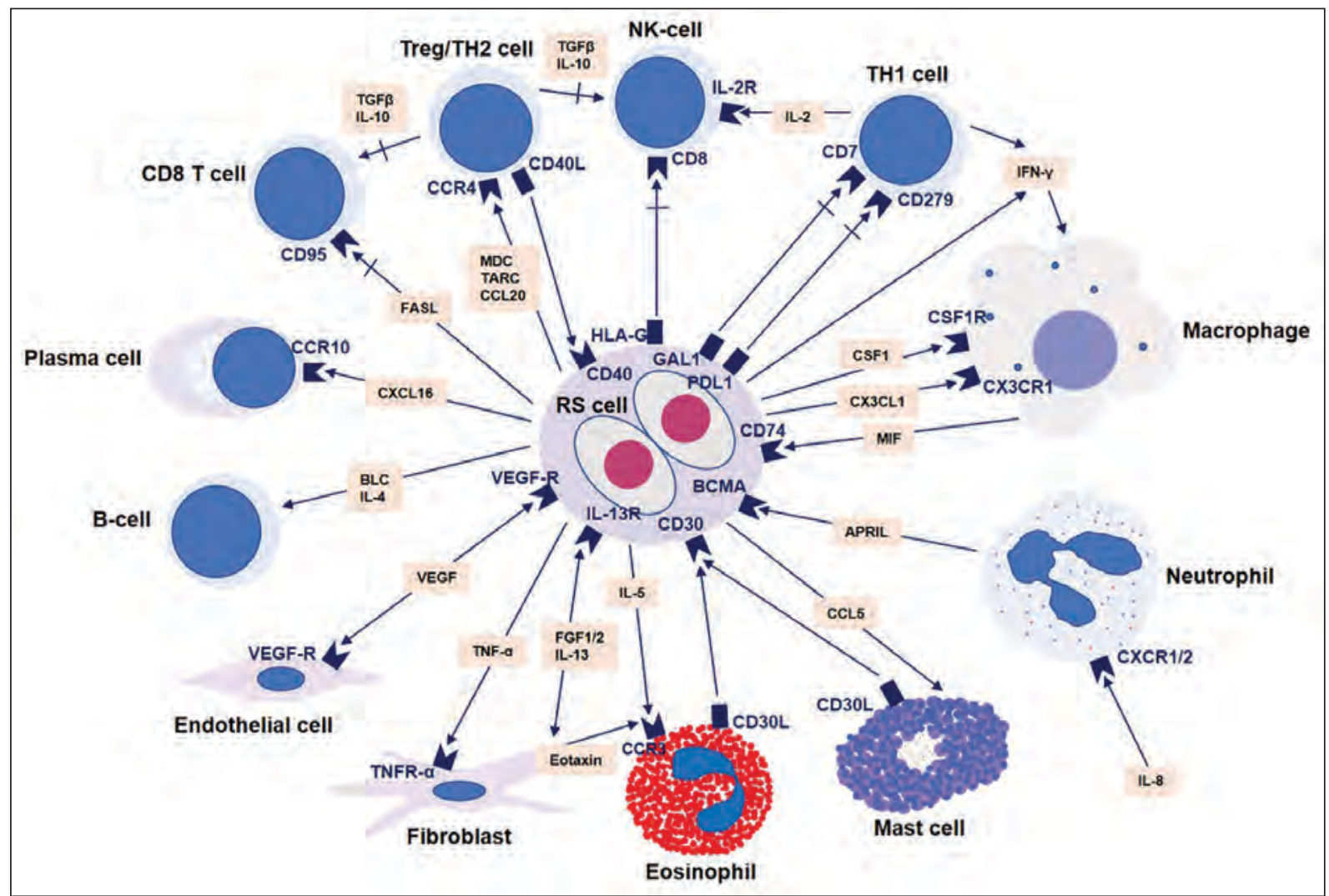

Figure 2. Complex interaction between neoplastic HRS cells and their microenvironment, mediated by cytokines and chemokines. APRIL, a proliferation-inducing ligand; BCL, B lymphocyte chemoattractant; BCMA, B-cell maturation antigen; $C C$, chemokine (C-C motif); CSF-1, colony stimulating factor-1; CXC, chemokine (C-X-C motif); FASL, Fas ligand; FGF, fibroblast growth factor; Gal-1, galectin-1; IFN- $\gamma$, interferon- $\gamma$; IL, interleukin; MDC, macrophage-derived chemokine; MIF, macrophage migration inhibitory factor; PDL1, programmed cell death 1 ligand; TARC, thymus and activation-related chemokine; TGF- $\beta$, transforming growth factor- $\beta$; TH, T helper cell; TNF, tumor necrosis factor; TNFR, tumor necrosis factor receptor; Treg, T regulatory cell; VEGF, vascular endothelial growth factor

neutrophils, mast cells, and stromal cells. Through very complex interaction with their microenvironment, mediated by cytokines and chemokines, HRS cells evade immune response, survive and grow (Figure 2) (57-60). The most abundant cells in the microenvironment are CD4+ T cells, mainly T helper 2 (TH2) and T regulatory (Treg) cells that express CCR4 receptor; however, the dominance of $\mathrm{TH} 2$ cells has recently been questioned and TH1 cells may be more important. Several chemokines, such as thymus and activation-related chemokine (TARC) and macrophage-derived chemokine (MDC), as well as CCL5 are secreted by HRS cells and attract TH2 and Treg cells via CCR4 receptor (59, 61-64). Macrophages are another very important cell subset in CHL microenviron- ment and were found to be prognostically relevant. The major cytokines produced by HRS cells that attract macrophages and enhance their function are interferon gamma, CSF1 and CXCL13. Macrophages, on the other hand, secrete macrophage migration inhibitory factor (MIF), which contributes to proliferation of RS cells (59, 65-67).

So-called "immune evasion" of HRS cells occurs through multiple mechanisms. Programmed death protein-1 (PD-1) is expressed in on activated T cells, B cells, macrophages, NK cells, Tregs and follicular $\mathrm{T}$ cells. Malignant cells of $\mathrm{CHL}$ highly express programmed death ligand-1 (PDL1) and programmed death ligand-2 (PD-L2). PD-1/PD-L1 binding leads to crosslinking of the antigen-T-cell receptor (TCR) complex with PD-1 
which results in attenuation of TCR-associated downstream signaling, decreased cytokine production, and inhibition of T-cell proliferation. In $\mathrm{CHL}$, copy number gains in $P D-L 1$ and $P D-L 2$ (9p24.1) are the main mechanisms for increase in PD-1 protein expression on malignant HRS cells. This leads to T-cell exhaustion (i.e. reduced T-cell activation, suppression of T-cell proliferation and cytokine production) in tumor microenvironment and contributes to immune escape (51, 68-74). Furthermore, amplification of 9p24.1 also results in JAK2 copy gain, increased JAK-STAT signaling, and increase in PD-1 ligand expression (51). Anti-PD-1 blocking antibodies have been successful in prolonging survival of patients with relapsed/refractory CHL $(12,15,16)$. Other genetic lesions that contribute to immune evasion of RS cells include translocations of the MHC class II transactivator (CIITA) gene, which result in gene inactivation, and downregulation of HLA class II molecules, as well as increased surface expression of PD-L1/L2 (75). Moreover, inactivating mutations of beta2-microglobulin (B2M) gene result in downregulation of HLA class I molecules (76).

\section{Cytogenetic Studies}

Classic Hodgkin lymphoma shows recurrent cytogenetic abnormalities, including copy number changes and translocations. Among the most frequent are amplifications of 9p24.1 locus, affecting $J A K 2, P D-L 1$ and $P D-L 2$ genes, as outlined above. Other copy number changes include gains of $2 \mathrm{p}$, $12 \mathrm{q}, 14 \mathrm{q}, 16 \mathrm{p}, 17 \mathrm{p}, 17 \mathrm{q}, 19 \mathrm{q}$, and $20 \mathrm{q}$; and losses of $4 \mathrm{q}, 6 \mathrm{q}, 11 \mathrm{q}$, and $13 \mathrm{q}(45,77,78)$. Translocations involving immunoglobulin loci $(I G)$ are common and can be seen in approximately $20 \%$ of cases. The partners were identified in a subset of cases and included REL (2p16), BCL6 (3q27), MYC (8q24), and BCL3/RELB (19q13.2) (79).

\section{Molecular Prognostic Models}

Several studies proposed molecular prognostic models in CHL patients with clinically advanced disease by combining expression of multiple genes
(80-82). Sanchez-Espiridion et al. (80) applied reverse-transcription polymerase chain reaction (RT-PCR) assay to 282 formalin-fixed paraffinembedded (FFPE) tissue samples of CHL patients with clinical stage III and IV, as well as stage IIB with bulky disease. They evaluated expression of 30 genes, including genes expressed by malignant cells and microenvironment and integrated best predictor genes into an 11-gene model. The model included four functional pathways - cell cycle, apoptosis, macrophage activation, and interferon regulatory factor 4 , and was able to identify a group of high-risk patients with significantly worse 5 -year failure free survival (FFS; $44.1 \%$ for highrisk vs. $74 \%$ for low-risk). Moreover, when combined with clinical stage IV this model identified a group of patients with particularly poor outcome. Scott et al. (81) evaluated expression levels of 259 genes (including genes associated with microenvironment and the cellular processes associated with outcomes in CHL) by NanoString platform on pretreatment FFPE tissue samples from $290 \mathrm{CHL}$ patients with locally extensive or advanced stage disease. Using penalized Cox regression, they created a prognostic model for overall survival (OS) comprising 23 genes. The model separated the patients into low- and high-risk groups (94\% vs. 75\% 5 -year OS) and was validated in an independent CHL cohort. Furthermore, this prognostic model was superior to IPS in the multivariate analysis. Chan et al. (82) constructed an interesting 30 gene model (so-called "RHL30") using FFPE CHL biopsies taken at disease relapse that predicted outcome post-autologous stem-cell transplantation (ASCT). Gene expression profiling was performed by using NanoString platform and the model included 18 outcome-associated and 12 housekeeping genes and included B-cell, macrophage, RScell, neutrophil and natural killer-cell signatures, as well as drug resistance signature. The model identified a group of patients with significantly lower 5-year post-ASCT OS (27.8\% for high-risk vs. $85.4 \%$ for low-risk) and FFS (23.8\% for highrisk vs. $77.5 \%$ for low-risk). In summary, these prognostic models are robust and conveniently performed on FFPE tissue samples. However, they 
require considerable technical and bioinformatics expertise and are unlikely to become routinely used in the near future.

\section{Immunohistochemical Prognostic Markers}

A number of immunohistochemical markers expressed on HRS cells, single or in combination, have been evaluated as prognosticators in CHL. Immunohistochemistry is widely available and relatively inexpensive; however, immunohistochemical studies frequently suffer from poor reproducibility due to differences in tissue fixation and processing, different antibody clones used, and significant interobserver variability (83). More commonly reported immunohistochemical prognostic markers are outlined in Table $3(30,84-97)$.
The most convincing findings appear to be the poorer prognosis associated with BCL2 and T-cell antigen expression by HRS cells $(84,87,88,91,94$, 95). Other reported markers associated with decreased survival and refractory disease are MAL and ABCC1 $(89,92)$. Studies that assessed expression of CD20 showed conflicting results and prognostic significance of CD20 expression in CHL is uncertain $(85,86,88,91)$. Interestingly, studies that assessed prognostic significance of PD-L1 also showed controversial results, including more favorable outcome and poorer prognosis. Ozturk et al. (97) reported poorer prognosis of PD-L1 positive patients. This study also found that overexpression of PD-1 in tumor microenvironment, together with positivity for EBV on RS cells, portends particularly unfavorable prognosis.

Table 3. Immunohistochemical Prognostic Markers Expressed on Hodgkin/Reed-Sternberg Cells in Classic Hodgkin Lymphoma

\begin{tabular}{|c|c|c|}
\hline Prognostic marker & Prognosis & Reference \\
\hline \multirow{4}{*}{ CD20 } & CD20+ - no prognostic significance & Rassidakis et al. (2002) \\
\hline & CD20+ - decreased OS and FFS & Portlock et al. (2004) \\
\hline & CD20+- no prognostic significance & Asano et al. (2006) \\
\hline & Decreased CD20 expression - associated with refractory disease or early relapse & Canioni et al. (2009) \\
\hline \multirow{4}{*}{$\mathrm{BCL} 2$} & BCL2+- decreased FFS & Rassidakis et al. (2002) \\
\hline & $\mathrm{BCL} 2+-$ decreased OS and FFS & Sup et al. (2005) \\
\hline & $\mathrm{BCL} 2+-$ associated with refractory disease or early relapse & Canioni et al. (2009) \\
\hline & BCL2+ - no prognostic significance & Koh et al. (2013) \\
\hline \multirow[b]{2}{*}{ PD-L1 } & PD-L1+ - increased FFS & Roemer et al. (2018)* \\
\hline & $\begin{array}{l}\text { PD-L1+ - associated with advanced disease; when combined with PD-1+ in } \\
\text { microenvironment and EBV+ HRS cells - very high-risk disease }\end{array}$ & Ozturk et al. (2020) \\
\hline \multirow{3}{*}{ MHC class I and II } & MHC class I+ - no prognostic significance & \multirow{2}{*}{ Roemer et al. (2018)* } \\
\hline & MHC class II+ - increased FFS & \\
\hline & MHC class II+ - increased FFS & Diepstra et al. (2007) \\
\hline HGAL & HGAL+ - improved OS and FFS & Natkunam et al. (2007) \\
\hline MAL & MAL+ - decreased OS and FFS & Hsi et al. (2006) \\
\hline$A B C C 1$ & $\begin{array}{l}\text { ABCC } 1+- \text { associated with refractory } \\
\text { disease and decreased FFS }\end{array}$ & Greaves et al. (2013) \\
\hline \multirow{3}{*}{ T-cell markers } & CD3, CD4, CD8, CD45RO, TIA-1, granzyme B - decreased OS & Asano et al. $(2006)^{\dagger}$ \\
\hline & $\mathrm{CD} 3, \mathrm{CD} 4, \mathrm{CD} 8, \mathrm{CD} 5, \mathrm{CD} 2, \mathrm{CD} 7$ - decreased OS and FFS & Venkataraman et al. $(2013)^{\ddagger}$ \\
\hline & $\mathrm{CD} 2, \mathrm{CD} 3, \mathrm{CD} 4, \mathrm{CD} 5, \mathrm{CD} 7, \mathrm{TIA}-1$ - no prognostic significance & Nguyen et al. (2016) \\
\hline
\end{tabular}

EBV=Epstein-Barr virus; FFS=Failure free survival; OS=Overall survival; HRS=Hodgkin/Reed-Sternberg; "Immunohistochemical markers were correlated with clinical responses and progression-free survival after anti PD-1 therapy (nivolumab); ${ }^{\dagger} 27$ cases in the study expressed different combinations of T-cell markers; $\mp 50$ cases in the study expressed different combinations of T-cell markers, most commonly CD4 and CD2. 


\section{Prognostic Markers Associated with Tumor Microenvironment}

The prognostic significance of the inflammatory microenvironment in CHL has been a topic of numerous studies. Tumor-associated macrophages and different T-cell subsets have been most studied, but also other cells such as B cells, plasma cells, and mast cells have also been investigated (Table 4) (91, 95, 98-109). Steidl et al. (103) analyzed 130 CHL samples using GEP, which identified a gene signature of tumor-associated macrophages that was associated with poorer prognosis. Numerous immunohistochemical studies have examined prognostic significance of macrophages in CHL microenvironment using CD68 and CD163 antibodies. The results of these studies vary, with some studies showing worse outcome with increased number of macrophages, while others found no impact on survival, suggesting that GEP results from the Steidl et al. (103) study are not consistently reproducible by immunohistochemistry. Guo et al. (107) performed a meta-analysis of 22 studies (2959 patients) that showed high-density of macrophages to be associated with decreased overall and failure-free survival. T-cells in the microenvironment were also found to be important prognostic marker, with increased number of $\mathrm{T}$ regulatory cells being associated with better prognosis, while increased number of cytotoxic $\mathrm{T}$ cells portends worse prognosis $(91,95,98-102,104)$.

\section{MicroRNA Signature}

MicroRNAs (miRNAs) are small non-coding RNA molecules that regulate important biologic processes such as proliferation and differentiation. Furthermore, they can act as oncogenes (on-

Table 4. Prognostic Markers Associated with Cells in Tumor Microenvironment of Classic Hodgkin Lymphoma

\begin{tabular}{|c|c|c|}
\hline Prognostic marker & Prognosis & Reference \\
\hline $\begin{array}{l}\text { Tumor-associated macrophages } \\
\text { IHC for CD68+/- CD163 }\end{array}$ & $\begin{array}{l}\text { High-density of CD68+ TAMs - decreased OS and FFS; poor DSS; } \\
\text { High-density of CD163+ TAMs - decreased OS and FFS }\end{array}$ & Guo et al. (2016)* \\
\hline \multirow{4}{*}{$\begin{array}{l}\text { T-cells Regulatory T cells } \\
\text { (FOXP3 IHC) }\end{array}$} & Increased number - increased OS and FFS & Tzankov et al. (2008) \\
\hline & Increased number - increased EFS & Chettaile et al. (2009) \\
\hline & Increased number - increased OS & Greaves et al. (2013) \\
\hline & Increased number (anergic signature) - decreased FFS & Hollander et al. (2018) \\
\hline \multirow{5}{*}{$\begin{array}{l}\text { Cytotoxic T cells } \\
\text { (TIA-1 or granzyme B IHC) }\end{array}$} & Increased number - decreased FFS & Oudejans et al. (1997) \\
\hline & Increased number - decreased OS and EFS & Alvaro-Naranjo et al. (2005) \\
\hline & Increased number - associated with refractory disease or early relapse & Canioni et al. (2009) \\
\hline & Increased number - decreased OS & Chettaile et al. (2009) \\
\hline & Increased number - decreased OS & Nguyen et al. (2016) \\
\hline $\begin{array}{l}\text { Ratio of regulatory } \\
T \text { cells to cytotoxic T cells }\end{array}$ & Ratio $\leq 1$ - decreased OS and FFS & Kelley et al. (2007) \\
\hline \multirow{3}{*}{ B-cells (CD20 IHC) } & Increased number - increased OS and EFS & Chettaile et al. (2009) \\
\hline & Increased density - increased OS & Greaves et al. (2013) \\
\hline & Increased number - increased OS and improved FFS & Panico et al. (2015) \\
\hline Plasma cells (CD138 IHC) & $\begin{array}{l}\text { High proportion of plasma cells - decreased OS and EFS; presence of } \\
\text { B-symptoms and advanced stage (IIB-IVB) }\end{array}$ & Gholika et al. (2019) \\
\hline \multirow{2}{*}{$\begin{array}{l}\text { Mast cells } \\
\text { (tryptase or CD117 IHC) }\end{array}$} & Increased number - associated with refractory disease or early relapse & Canioni et al. (2009) \\
\hline & High number in CHL-MC - decreased OS and $\mathrm{EFS}^{+}$ & Andersen et al. (2016) \\
\hline
\end{tabular}

$\mathrm{CHL}-\mathrm{MC}=$ Classic Hodgkin lymphoma, mixed cellularity; DSS=Disease-specific survival; $\mathrm{EFS=event-free} \mathrm{survival;} F F S=f a i l u r e-f r e e ~ s u r v i v a l ; ~ I H C=I m m u n o h i s-$ tochemistry; OS=Overall survival; TAM=Tumor-associated macrophage; "Meta-analysis of 22 studies with 2959 patients; some studies in the literature showed no impact on survival; 'Degree of mast cell infiltration not prognostic in classic Hodgkin lymphoma, nodular sclerosis subtype. 
comirs) and tumor suppressor genes and have an important role in carcinogenesis, including lymphoma development (110-112). Sanchez-Espiridion et al. (113) performed miRNA microarray hybridization to define HRS and microenvironment miRNA signatures on frozen tissue samples from 29 CHL patients with advanced clinical stage. They identified CHL-miRNA signature with 234 differentially expressed miRNAs, a subset of which was prognostic. Quantitative polymerase chain reaction (Q-PCR) was performed to evaluate expression of miRNA associated with clinical outcome in an independent cohort of 168 FFPE CHL samples. Ultimately, a miRNA signature that included MIR21, MIR30E, MIR30D, and MIR92B ${ }^{\star}$ stratified patients into two risk groups with significantly different 5-year FFS (35.7\% for high-risk vs. $81 \%$ for low-risk).

\section{Peripheral Blood Prognostic Markers and Circulating Tumor DNA}

Several papers have investigated the role of peripheral blood prognostic markers in CHL; some of these markers are novel and can be used to assess the response to therapy. Poratta et al. (114) reported that peripheral blood lymphocyte/monocyte ratio $\geq 1.1$ was associated with increased OS and PFS. Koh and al. (115) found that patients with absolute neutrophil count/absolute lymphocyte count $\geq 4.3$ had decreased OS. Galectin-1, a carbohydrate-binding protein that plays an important role in immune response and fosters immune escape by tumor, was found to be expressed on HRS cells in CHL (116). Subsequently, Ouyang et al. (117) found that serum levels of galectin-1 are higher in CHL patients that in normal controls. Moreover, higher levels correlated with advanced clinical stage and higher IPS. Hsi et al. (118) analyzed levels of serum soluble chemokines/cytokines produced by HRS cells including TARC, MDC, interleukin-10 (IL-10) and soluble CD163 (sCD163). None of the markers were associated with outcome at diagnosis/baseline. At the time of interim PET study, increased levels of sCD163 were associated with favorable PFS. Furthermore, increased levels of TARC, MDC and IL-10 at the end of therapy were associated with shorter survival, making these markers useful in potentially identifying the patients at higher risk for relapse.

Circulating tumor (ct) DNA analysis by NGS is a particularly attractive approach in CHL and it could become complementary method to tissue biopsy in the near future. There are several possible applications of ctDNA analysis in CHL, including making diagnosis (especially in cases where tumor mass is difficult to biopsy and when biopsy is scant), evaluating response to treatment including minimal residual disease, as well as in prognostication to identify patients who are likely to experience disease relapse $(55,119-122)$. Several studies showed that mutations detected by analyzing ctDNA mirrored mutations in the corresponding tissue biopsies $(55,119)$. Higher plasma ctDNA levels at diagnosis were associated with unfavorable clinical characteristics (120). Moreover, in patients who responded well to chemotherapy and had negative PET staging ctDNA became undetectable, while in patients with partial response or refractory disease ctDNA remained detectable (119-122). These findings are important and indicate that ctDNA could be routinely used in disease monitoring after therapy and potentially decrease exposure to radiation from imaging techniques, as well as decrease the need for invasive tissue biopsies.

\section{Epstein-Barr Virus (EBV) - Role in Pathogenesis}

Epstein-Barr virus, a member of herpes virus family (a.k.a. Human herpesvirus 4), is an important etiological factor in number of human neoplasms, and is of particular interest in the field of lymphoma pathology (2). Epstein-Barr virus is detected in approximately $20-25 \%$ of CHL cases, with viral genomes in monoclonal form. Current "gold standard" for its detection in pathology practice is the EBV-encoded small RNA EBER1. Among the four histologic subtypes, EBV is most consistently and most frequently seen in mixed cellularity subtype $(123,124)$. The epidemiology of EBV-positive CHL 
shows distinct patterns of distribution depending on age, as well as geographic and racial differences. Distribution of EBV-positive CHL cases varies around the world and is generally higher in the resource-poor countries, and more prevalent among Asians and Hispanics, compared to whites and Blacks. As for age, EBV+ cases are common in childhood, uncommon in young adults, and again common among older patients $(123,125)$. The reasons for these differences are not entirely clear, but are likely multifactorial and related to age of first exposure to EBV, genetic background, and changes in immune system related to disease and aging (so-called immunosenescence) $(124,126)$. People with a history of infectious mononucleosis have several times increased risk of EBV-positive CHL (127). Also, majority of CHL cases in HIV-positive individuals are EBV-positive (128).

Epstein-Barr virus contributes directly to $\mathrm{CHL}$ pathogenesis, via its EBV-encoded proteins, including nuclear antigens (EBNAs), latent membrane proteins (LMP1, LMP2A, and LMP2B), noncoding Epstein-Barr-encoded RNAs (EBER1 and EBER2) as well as miRNAs expressed in infected RS cells. Classic Hodgkin lymphoma is characterized by so-called type II latency pattern, which includes expression of EBNA-1, LMP-1, LMP-2, EBERs, and BART miRNAs (129-131). LMP-1 is similar to constitutively activated CD40 receptor, which leads to induction of JAK/STAT, NF- $\kappa B$, and PI3K-AKT signaling pathways (132138). LMP1 also induces PD-L1 expression, contributing to immune evasion (139). EBNA1 contributes to pathogenesis of CHL in several ways, such as inhibiting TGF $\beta$ signaling and upregulation of chemokine CCL20 in RS cells, which promotes migration of regulatory $\mathrm{T}$ cells (140-142). LMP2 mimics BCR, which allows for B-cell development in the absence of normal BCR signaling. LMP activates cellular pathways required for B-cell survival and can immortalize BCR-negative germinal center B-cells (143-145). The tumor microenvironment in EBV-positive CHL cases is characterized by increased numbers of cytotoxic $T$ cells and significantly higher number of macrophages, compared to EBV-negative cases $(98,102$,
146). Prognosis of EBV-positive CHL in elderly population is worse than EBV-negative cases. The choice of treatment for this group of patients are PD-1 inhibitors, which are showing very promising results $(147,148)$.

\section{Conclusions}

Over the past two decades numerous studies have contributed to our understanding of molecular mechanisms of CHL pathogenesis and complex interactions between HRS cells and their inflammatory microenvironment. These discoveries opened many avenues for targeted therapies, some of which are already in routine use in CHL management. The prognosis of CHL is overall favorable with modern therapies, however, up to $30 \%$ of patients will experience disease relapse and a small subset is refractory to treatment (12). A number of biological prognostic models and single markers have been proposed to improve risk stratification of CHL patients. Most of these prognostic markers are not routinely implemented at initial diagnosis of CHL, but this will likely change in the future as the goals of CHL therapy, like in other neoplasms, are to achieve sustainable remission, prevent relapse, and minimize toxicity. In the era of personalized medicine "one size does not fit all", and CHL is a prime example of this concept.

Conflict of Interest: The authors declare that they have no conflict of interest.

\section{References}

1. Laurent C, Do C, Gourraud PA, de Paiva GR, Valmary S, Brousset P. Prevalence of Common Non-Hodgkin Lymphomas and Subtypes of Hodgkin Lymphoma by Nodal Site of Involvement: A Systematic Retrospective Review of 938 Cases. Medicine (Baltimore). 2015;94(25):e987.

2. Swerdlow SH, Campo E, Harris NL, Jaffe ES, Pileri SA, Stein $\mathrm{H}$, et al. WHO Classification of Tumours of Haematopoietic and Lymphoid Tissues. Lyon: IARC; 2017.

3. Hodgkin. On some Morbid Appearances of the Absorbent Glands and Spleen. Med Chir Trans. 1832;17:68-114.

4. Reed. On the Pathological Changes in Hodgkin's Disease, with Special Reference to Its Relation to Tuberculosis. Johns Hopkins Hosp Rep. 1902;10:133-96. 
5. Kuppers R, Rajewsky K, Zhao M, Simons G, Laumann R, Fischer R, et al. Hodgkin disease: Hodgkin and ReedSternberg cells picked from histological sections show clonal immunoglobulin gene rearrangements and appear to be derived from B cells at various stages of development. Proc Natl Acad Sci U S A. 1994;91(23):10962-6.

6. Pileri SA, Leoncini L, Falini B. Revised EuropeanAmerican Lymphoma Classification. Curr Opin Oncol. 1995;7(5):401-7.

7. Kanzler H, Kuppers R, Hansmann ML, Rajewsky K. Hodgkin and Reed-Sternberg cells in Hodgkin's disease represent the outgrowth of a dominant tumor clone derived from (crippled) germinal center B cells. J Exp Med. 1996;184(4):1495-505.

8. Glaser SL, Jarrett RF. The epidemiology of Hodgkin's disease. Baillieres Clin Haematol. 1996;9(3):401-16.

9. Siegel R, Naishadham D, Jemal A. Cancer statistics, 2013. CA Cancer J Clin. 2013;63(1):11-30.

10. Jaffe ES, Arber DA, Campo E, Harris NL, QuintanillaMartinez L. Hematopathology. 2nd ed. Philadelphia, PA: Elsevier; 2017.

11. Munker R, Hasenclever D, Brosteanu O, Hiller E, Diehl V. Bone marrow involvement in Hodgkin's disease: an analysis of 135 consecutive cases. German Hodgkin's Lymphoma Study Group. J Clin Oncol. 1995;13(2):403-9.

12. Ansell SM. Hodgkin lymphoma: A 2020 update on diagnosis, risk-stratification, and management. Am J Hematol. 2020;95(8):978-89.

13. Jerusalem G, Beguin Y, Fassotte MF, Najjar F, Paulus P, Rigo P, et al. Whole-body positron emission tomography using 18F-fluorodeoxyglucose for posttreatment evaluation in Hodgkin's disease and non-Hodgkin's lymphoma has higher diagnostic and prognostic value than classical computed tomography scan imaging. Blood. 1999;94(2):429-33.

14. Younes A, Gopal AK, Smith SE, Ansell SM, Rosenblatt JD, Savage KJ, et al. Results of a pivotal phase II study of brentuximab vedotin for patients with relapsed or refractory Hodgkin's lymphoma. J Clin Oncol. 2012;30(18):2183-9.

15. Armand P, Engert A, Younes A, Fanale M, Santoro A, Zinzani PL, et al. Nivolumab for Relapsed/Refractory Classic Hodgkin Lymphoma After Failure of Autologous Hematopoietic Cell Transplantation: Extended FollowUp of the Multicohort Single-Arm Phase II CheckMate 205 Trial. J Clin Oncol. 2018;36(14):1428-39.

16. Chen R, Zinzani PL, Lee HJ, Armand P, Johnson NA, Brice $\mathrm{P}$, et al. Pembrolizumab in relapsed or refractory Hodgkin lymphoma: 2-year follow-up of KEYNOTE-087. Blood. 2019;134(14):1144-53.

17. Diehl V, Stein H, Hummel M, Zollinger R, Connors JM. Hodgkin's lymphoma: biology and treatment strategies for primary, refractory, and relapsed disease. Hematology Am Soc Hematol Educ Program. 2003:225-47.
18. Hasenclever D, Diehl V. A prognostic score for advanced Hodgkin's disease. International Prognostic Factors Project on Advanced Hodgkin's Disease. N Engl J Med. 1998;339(21):1506-14.

19. Moccia AA, Donaldson J, Chhanabhai M, Hoskins PJ, Klasa RJ, Savage KJ, et al. International Prognostic Score in advanced-stage Hodgkin's lymphoma: altered utility in the modern era. J Clin Oncol. 2012;30(27):3383-8.

20. Shiels MS, Koritzinsky EH, Clarke CA, Suneja G, Morton LM, Engels EA. Prevalence of HIV Infection among U.S. Hodgkin lymphoma cases. Cancer Epidemiol Biomarkers Prev. 2014;23(2):274-81.

21. Pinkus GS, Thomas P, Said JW. Leu-M1--a marker for Reed-Sternberg cells in Hodgkin's disease. An immunoperoxidase study of paraffin-embedded tissues. Am J Pathol. 1985;119(2):244-52.

22. Dorfman RF, Gatter KC, Pulford KA, Mason DY. An evaluation of the utility of anti-granulocyte and anti-leukocyte monoclonal antibodies in the diagnosis of Hodgkin's disease. Am J Pathol. 1986;123(3):508-19.

23. Schwarting R, Gerdes J, Durkop H, Falini B, Pileri S, Stein H. BER-H2: a new anti-Ki-1 (CD30) monoclonal antibody directed at a formol-resistant epitope. Blood. 1989;74(5):1678-89.

24. Said JW. The immunohistochemistry of Hodgkin's disease. Semin Diagn Pathol. 1992;9(4):265-71.

25. von Wasielewski R, Mengel M, Fischer R, Hansmann ML, Hubner K, Franklin J, et al. Classical Hodgkin's disease. Clinical impact of the immunophenotype. Am J Pathol. 1997;151(4):1123-30.

26. Browne P, Petrosyan K, Hernandez A, Chan JA. The Bcell transcription factors BSAP, Oct-2, and BOB.1 and the pan-B-cell markers CD20, CD22, and CD79a are useful in the differential diagnosis of classic Hodgkin lymphoma. Am J Clin Pathol. 2003;120(5):767-77.

27. Schmid C, Pan L, Diss T, Isaacson PG. Expression of Bcell antigens by Hodgkin's and Reed-Sternberg cells. Am J Pathol. 1991;139(4):701-7.

28. Zukerberg LR, Collins AB, Ferry JA, Harris NL. Coexpression of CD15 and CD20 by Reed-Sternberg cells in Hodgkin's disease. Am J Pathol. 1991;139(3):475-83.

29. McCune RC, Syrbu SI, Vasef MA. Expression profiling of transcription factors Pax-5, Oct-1, Oct-2, BOB.1, and PU.1 in Hodgkin's and non-Hodgkin's lymphomas: a comparative study using high throughput tissue microarrays. Mod Pathol. 2006;19(7):1010-8.

30. Natkunam Y, Hsi ED, Aoun P, Zhao S, Elson P, Pohlman $\mathrm{B}$, et al. Expression of the human germinal center-associated lymphoma (HGAL) protein identifies a subset of classic Hodgkin lymphoma of germinal center derivation and improved survival. Blood. 2007;109(1):298-305.

31. Agostinelli C, Paterson JC, Gupta R, Righi S, Sandri F, Piccaluga PP, et al. Detection of LIM domain only 2 (LMO2) in normal human tissues and haematopoietic and non- 
haematopoietic tumours using a newly developed rabbit monoclonal antibody. Histopathology. 2012;61(1):33-46.

32. Menter T, Gasser A, Juskevicius D, Dirnhofer S, Tzankov A. Diagnostic Utility of the Germinal Center-associated Markers GCET1, HGAL, and LMO2 in Hematolymphoid Neoplasms. Appl Immunohistochem Mol Morphol. 2015;23(7):491-8.

33. Aladily TN, Mansour A, Alsughayer A, Sughayer M, Medeiros LJ. The utility of CD83, fascin and CD23 in the differential diagnosis of primary mediastinal large B-cell lymphoma versus classic Hodgkin lymphoma. Ann Diagn Pathol. 2019;40:72-6.

34. Marafioti T, Hummel M, Foss HD, Laumen H, Korbjuhn P, Anagnostopoulos I, et al. Hodgkin and reed-sternberg cells represent an expansion of a single clone originating from a germinal center B-cell with functional immunoglobulin gene rearrangements but defective immunoglobulin transcription. Blood. 2000;95(4):1443-50.

35. Schwering I, Brauninger A, Klein U, Jungnickel B, Tinguely M, Diehl V, et al. Loss of the B-lineage-specific gene expression program in Hodgkin and Reed-Sternberg cells of Hodgkin lymphoma. Blood. 2003;101(4):1505-12.

36. Mathas S, Hartmann S, Kuppers R. Hodgkin lymphoma: Pathology and biology. Semin Hematol. 2016;53(3):139-47.

37. Renne C, Martin-Subero JI, Eickernjager M, Hansmann ML, Kuppers R, Siebert R, et al. Aberrant expression of ID2, a suppressor of B-cell-specific gene expression, in Hodgkin's lymphoma. Am J Pathol. 2006;169(2):655-64.

38. Ushmorov A, Leithauser F, Sakk O, Weinhausel A, Popov SW, Moller P, et al. Epigenetic processes play a major role in B-cell-specific gene silencing in classical Hodgkin lymphoma. Blood. 2006;107(6):2493-500.

39. Jundt F, Acikgoz O, Kwon SH, Schwarzer R, Anagnostopoulos I, Wiesner B, et al. Aberrant expression of Notch1 interferes with the B-lymphoid phenotype of neoplastic B cells in classical Hodgkin lymphoma. Leukemia. 2008;22(8):1587-94.

40. Mottok A, Steidl C. Biology of classical Hodgkin lymphoma: implications for prognosis and novel therapies. Blood. 2018;131(15):1654-65.

41. Jungnickel B, Staratschek-Jox A, Brauninger A, Spieker T, Wolf J, Diehl V, et al. Clonal deleterious mutations in the IkappaBalpha gene in the malignant cells in Hodgkin's lymphoma. J Exp Med. 2000;191(2):395-402.

42. Barth TF, Martin-Subero JI, Joos S, Menz CK, Hasel C, Mechtersheimer $G$, et al. Gains of $2 p$ involving the REL locus correlate with nuclear c-Rel protein accumulation in neoplastic cells of classical Hodgkin lymphoma. Blood. 2003;101(9):3681-6.

43. Martin-Subero JI, Wlodarska I, Bastard C, Picquenot JM, Hoppner J, Giefing $\mathrm{M}$, et al. Chromosomal rearrangements involving the BCL3 locus are recurrent in classical Hodgkin and peripheral T-cell lymphoma. Blood. 2006;108(1):401-2; author reply 2-3.
44. Schmitz R, Hansmann ML, Bohle V, Martin-Subero JI, Hartmann S, Mechtersheimer G, et al. TNFAIP3 (A20) is a tumor suppressor gene in Hodgkin lymphoma and primary mediastinal B cell lymphoma. J Exp Med. 2009;206(5):981-9.

45. Steidl C, Telenius A, Shah SP, Farinha P, Barclay L, Boyle $\mathrm{M}$, et al. Genome-wide copy number analysis of Hodgkin Reed-Sternberg cells identifies recurrent imbalances with correlations to treatment outcome. Blood. 2010;116(3):418-27.

46. Mansouri L, Noerenberg D, Young E, Mylonas E, Abdulla M, Frick M, et al. Frequent NFKBIE deletions are associated with poor outcome in primary mediastinal B-cell lymphoma. Blood. 2016;128(23):2666-70.

47. Joos S, Kupper M, Ohl S, von Bonin F, Mechtersheimer G, Bentz $\mathrm{M}$, et al. Genomic imbalances including amplification of the tyrosine kinase gene JAK2 in CD30+ Hodgkin cells. Cancer Res. 2000;60(3):549-52.

48. Hinz M, Lemke P, Anagnostopoulos I, Hacker C, Krappmann D, Mathas S, et al. Nuclear factor kappaBdependent gene expression profiling of Hodgkin's disease tumor cells, pathogenetic significance, and link to constitutive signal transducer and activator of transcription $5 \mathrm{a}$ activity. J Exp Med. 2002;196(5):605-17.

49. Skinnider BF, Elia AJ, Gascoyne RD, Patterson B, Trumper L, Kapp U, et al. Signal transducer and activator of transcription 6 is frequently activated in Hodgkin and Reed-Sternberg cells of Hodgkin lymphoma. Blood. 2002;99(2):618-26.

50. Weniger MA, Melzner I, Menz CK, Wegener S, Bucur AJ, Dorsch K, et al. Mutations of the tumor suppressor gene SOCS-1 in classical Hodgkin lymphoma are frequent and associated with nuclear phospho-STAT5 accumulation. Oncogene. 2006;25(18):2679-84.

51. Green MR, Monti S, Rodig SJ, Juszczynski P, Currie T, O'Donnell E, et al. Integrative analysis reveals selective 9p24.1 amplification, increased PD-1 ligand expression, and further induction via JAK2 in nodular sclerosing Hodgkin lymphoma and primary mediastinal large B-cell lymphoma. Blood. 2010;116(17):3268-77.

52. Gunawardana J, Chan FC, Telenius A, Woolcock B, Kridel $\mathrm{R}$, Tan KL, et al. Recurrent somatic mutations of PTPN1 in primary mediastinal B cell lymphoma and Hodgkin lymphoma. Nat Genet. 2014;46(4):329-35.

53. Kuppers R, Engert A, Hansmann ML. Hodgkin lymphoma. J Clin Invest. 2012;122(10):3439-47.

54. Mata E, Diaz-Lopez A, Martin-Moreno AM, SanchezBeato M, Varela I, Mestre MJ, et al. Analysis of the mutational landscape of classic Hodgkin lymphoma identifies disease heterogeneity and potential therapeutic targets. Oncotarget. 2017;8(67):111386-95.

55. Liang WS, Vergilio JA, Salhia B, Huang HJ, Oki Y, Garrido-Laguna I, et al. Comprehensive Genomic Profiling of Hodgkin Lymphoma Reveals Recurrently Mutated 
Genes and Increased Mutation Burden. Oncologist. 2019;24(2):219-28.

56. Mata E, Fernandez S, Astudillo A, Fernandez R, GarciaCosio M, Sanchez-Beato M, et al. Genomic analyses of microdissected Hodgkin and Reed-Sternberg cells: mutations in epigenetic regulators and p53 are frequent in refractory classic Hodgkin lymphoma. Blood Cancer J. 2019;9(3):34.

57. Teruya-Feldstein J, Tosato G, Jaffe ES. The role of chemokines in Hodgkin's disease. Leuk Lymphoma. 2000;38(34):363-71.

58. Skinnider BF, Mak TW. The role of cytokines in classical Hodgkin lymphoma. Blood. 2002;99(12):4283-97.

59. Steidl C, Connors JM, Gascoyne RD. Molecular pathogenesis of Hodgkin's lymphoma: increasing evidence of the importance of the microenvironment. J Clin Oncol. 2011;29(14):1812-26.

60. King RL, Howard MT, Bagg A. Hodgkin lymphoma: pathology, pathogenesis, and a plethora of potential prognostic predictors. Adv Anat Pathol. 2014;21(1):12-25.

61. van den Berg A, Visser L, Poppema S. High expression of the CC chemokine TARC in Reed-Sternberg cells. A possible explanation for the characteristic T-cell infiltratein Hodgkin's lymphoma. Am J Pathol. 1999;154(6):1685-91.

62. Peh SC, Kim LH, Poppema S. TARC, a CC chemokine, is frequently expressed in classic Hodgkin's lymphoma but not in NLP Hodgkin's lymphoma, T-cell-rich B-cell lymphoma, and most cases of anaplastic large cell lymphoma. Am J Surg Pathol. 2001;25(7):925-9.

63. Ohshima K, Tutiya T, Yamaguchi T, Suzuki K, Suzumiya J, Kawasaki C, et al. Infiltration of Th1 and Th2 lymphocytes around Hodgkin and Reed-Sternberg (H\&RS) cells in Hodgkin disease: Relation with expression of CXC and CC chemokines on H\&RS cells. Int J Cancer. 2002;98(4):567-72.

64. Fischer M, Juremalm M, Olsson N, Backlin C, Sundstrom C, Nilsson K, et al. Expression of CCL5/RANTES by Hodgkin and Reed-Sternberg cells and its possible role in the recruitment of mast cells into lymphomatous tissue. Int J Cancer. 2003;107(2):197-201.

65. Gerdes J, Kretschmer C, Zahn G, Ernst M, Jones DB, Flad HD. Immunoenzymatic assessment of interferongamma in Hodgkin and Sternberg-Reed cells. Cytokine. 1990;2(4):307-10.

66. Hsu PL, Lin YC, Hsu SM. Expression of macrophage colony-stimulating factor (M-CSF) in two Hodgkin's ReedSternberg (H-RS) cell lines, HDLM-1 and KM-H2, and in H-RS cells in tissues. Int J Hematol. 1991;54(4):315-26.

67. Truman LA, Ford CA, Pasikowska M, Pound JD, Wilkinson SJ, Dumitriu IE, et al. CX3CL1/fractalkine is released from apoptotic lymphocytes to stimulate macrophage chemotaxis. Blood. 2008;112(13):5026-36.

68. Keir ME, Butte MJ, Freeman GJ, Sharpe AH. PD-1 and its ligands in tolerance and immunity. Annu Rev Immunol. 2008;26:677-704.
69. Chen L, Flies DB. Molecular mechanisms of T cell co-stimulation and co-inhibition. Nat Rev Immunol. 2013;13(4):227-42.

70. Baumeister SH, Freeman GJ, Dranoff G, Sharpe AH. Coinhibitory Pathways in Immunotherapy for Cancer. Annu Rev Immunol. 2016;34:539-73.

71. Boussiotis VA. Molecular and Biochemical Aspects of the PD-1 Checkpoint Pathway. N Engl J Med. 2016;375(18):1767-78.

72. Zou W, Wolchok JD, Chen L. PD-L1 (B7-H1) and PD-1 pathway blockade for cancer therapy: Mechanisms, response biomarkers, and combinations. Sci Transl Med. 2016;8(328):328rv4.

73. Gordon SR, Maute RL, Dulken BW, Hutter G, George $\mathrm{BM}, \mathrm{McCracken} \mathrm{MN}$, et al. PD-1 expression by tumourassociated macrophages inhibits phagocytosis and tumour immunity. Nature. 2017;545(7655):495-9.

74. Liu WR, Shipp MA. Signaling pathways and immune evasion mechanisms in classical Hodgkin lymphoma. Blood. 2017;130(21):2265-70.

75. Steidl C, Shah SP, Woolcock BW, Rui L, Kawahara M, Farinha $\mathrm{P}$, et al. MHC class II transactivator CIITA is a recurrent gene fusion partner in lymphoid cancers. Nature. 2011;471(7338):377-81.

76. Reichel J, Chadburn A, Rubinstein PG, Giulino-Roth L, Tam W, Liu Y, et al. Flow sorting and exome sequencing reveal the oncogenome of primary Hodgkin and ReedSternberg cells. Blood. 2015;125(7):1061-72.

77. Joos S, Menz CK, Wrobel G, Siebert R, Gesk S, Ohl S, et al. Classical Hodgkin lymphoma is characterized by recurrent copy number gains of the short arm of chromosome 2. Blood. 2002;99(4):1381-7.

78. Borchmann S, Engert A. The genetics of Hodgkin lymphoma: an overview and clinical implications. Curr Opin Oncol. 2017;29(5):307-14.

79. Martin-Subero JI, Klapper W, Sotnikova A, Callet-Bauchu E, Harder L, Bastard C, et al. Chromosomal breakpoints affecting immunoglobulin loci are recurrent in Hodgkin and Reed-Sternberg cells of classical Hodgkin lymphoma. Cancer Res. 2006;66(21):10332-8.

80. Sanchez-Espiridion B, Montalban C, Lopez A, Menarguez J, Sabin P, Ruiz-Marcellan C, et al. A molecular risk score based on 4 functional pathways for advanced classical Hodgkin lymphoma. Blood. 2010;116(8):e12-7.

81. Scott DW, Chan FC, Hong F, Rogic S, Tan KL, Meissner B, et al. Gene expression-based model using formalin-fixed paraffin-embedded biopsies predicts overall survival in advanced-stage classical Hodgkin lymphoma. J Clin Oncol. 2013;31(6):692-700.

82. Chan FC, Mottok A, Gerrie AS, Power M, Nijland M, Diepstra A, et al. Prognostic Model to Predict Post-Autologous Stem-Cell Transplantation Outcomes in Classical Hodgkin Lymphoma. J Clin Oncol. 2017;35(32):3722-33. 
83. de Jong D, Rosenwald A, Chhanabhai M, Gaulard P, Klapper $\mathrm{W}$, Lee $\mathrm{A}$, et al. Immunohistochemical prognostic markers in diffuse large B-cell lymphoma: validation of tissue microarray as a prerequisite for broad clinical applications--a study from the Lunenburg Lymphoma Biomarker Consortium. J Clin Oncol. 2007;25(7):805-12.

84. Rassidakis GZ, Medeiros LJ, Vassilakopoulos TP, Viviani S, Bonfante V, Nadali G, et al. BCL-2 expression in Hodgkin and Reed-Sternberg cells of classical Hodgkin disease predicts a poorer prognosis in patients treated with ABVD or equivalent regimens. Blood. 2002;100(12):3935-41.

85. Rassidakis GZ, Medeiros LJ, Viviani S, Bonfante V, Nadali GP, Vassilakopoulos TP, et al. CD20 expression in Hodgkin and Reed-Sternberg cells of classical Hodgkin's disease: associations with presenting features and clinical outcome. J Clin Oncol. 2002;20(5):1278-87.

86. Portlock CS, Donnelly GB, Qin J, Straus D, Yahalom J, Zelenetz A, et al. Adverse prognostic significance of CD20 positive Reed-Sternberg cells in classical Hodgkin's disease. Br J Haematol. 2004;125(6):701-8.

87. Sup SJ, Alemany CA, Pohlman B, Elson P, Malhi S, Thakkar S, et al. Expression of bcl-2 in classical Hodgkin's lymphoma: an independent predictor of poor outcome. J Clin Oncol. 2005;23(16):3773-9.

88. Asano N, Oshiro A, Matsuo K, Kagami Y, Ishida F, Suzuki $\mathrm{R}$, et al. Prognostic significance of T-cell or cytotoxic molecules phenotype in classical Hodgkin's lymphoma: a clinicopathologic study. J Clin Oncol. 2006;24(28):4626-33.

89. Hsi ED, Sup SJ, Alemany C, Tso E, Skacel M, Elson P, et al. MAL is expressed in a subset of Hodgkin lymphoma and identifies a population of patients with poor prognosis. Am J Clin Pathol. 2006;125(5):776-82.

90. Diepstra A, van Imhoff GW, Karim-Kos HE, van den Berg A, te Meerman GJ, Niens M, et al. HLA class II expression by Hodgkin Reed-Sternberg cells is an independent prognostic factor in classical Hodgkin's lymphoma. J Clin Oncol. 2007;25(21):3101-8.

91. Canioni D, Deau-Fischer B, Taupin P, Ribrag V, Delarue R, Bosq J, et al. Prognostic significance of new immunohistochemical markers in refractory classical Hodgkin lymphoma: a study of 59 cases. PLoS One. 2009;4(7):e6341.

92. Greaves W, Xiao L, Sanchez-Espiridion B, Kunkalla K, Dave KS, Liang CS, et al. Detection of ABCC1 expression in classical Hodgkin lymphoma is associated with increased risk of treatment failure using standard chemotherapy protocols. J Hematol Oncol. 2012;5:47.

93. Koh YW, Park C, Yoon DH, Suh C, Huh J. Prognostic significance of COX-2 expression and correlation with Bcl-2 and VEGF expression, microvessel density, and clinical variables in classical Hodgkin lymphoma. Am J Surg Pathol. 2013;37(8):1242-51.

94. Venkataraman G, Song JY, Tzankov A, Dirnhofer S, Heinze G, Kohl M, et al. Aberrant T-cell antigen expression in classical Hodgkin lymphoma is associated with decreased event-free survival and overall survival. Blood. 2013;121(10):1795-804.

95. Nguyen TT, Frater JL, Klein J, Chen L, Bartlett NL, Foyil KV, et al. Expression of TIA1 and PAX5 in Classical Hodgkin Lymphoma at Initial Diagnosis May Predict Clinical Outcome. Appl Immunohistochem Mol Morphol. 2016;24(6):383-91.

96. Roemer MGM, Redd RA, Cader FZ, Pak CJ, Abdelrahman S, Ouyang J, et al. Major Histocompatibility Complex Class II and Programmed Death Ligand 1 Expression Predict Outcome After Programmed Death 1 Blockade in Classic Hodgkin Lymphoma. J Clin Oncol. 2018;36(10):942-50.

97. Ozturk V, Yikilmaz AS, Kilicarslan A, Bakanay SM, Akinci S, Dilek I. The Triple Positivity for EBV, PD1, and PD-L1 Identifies a Very High Risk Classical Hodgkin Lymphoma. Clin Lymphoma Myeloma Leuk. 2020;20(7):e375-81.

98. Oudejans JJ, Jiwa NM, Kummer JA, Ossenkoppele GJ, van Heerde P, Baars JW, et al. Activated cytotoxic T cells as prognostic marker in Hodgkin's disease. Blood. 1997;89(4):1376-82.

99. Alvaro-Naranjo T, Lejeune M, Salvado-Usach MT, Bosch-Princep R, Reverter-Branchat G, Jaen-Martinez J, et al. Tumor-infiltrating cells as a prognostic factor in Hodgkin's lymphoma: a quantitative tissue microarray study in a large retrospective cohort of 267 patients. Leuk Lymphoma. 2005;46(11):1581-91.

100. Kelley TW, Pohlman B, Elson P, Hsi ED. The ratio of FOXP3+ regulatory $\mathrm{T}$ cells to granzyme $\mathrm{B}+$ cytotoxic $\mathrm{T} /$ NK cells predicts prognosis in classical Hodgkin lymphoma and is independent of bcl-2 and MAL expression. Am J Clin Pathol. 2007;128(6):958-65.

101. Tzankov A, Meier C, Hirschmann P, Went P, Pileri SA, Dirnhofer S. Correlation of high numbers of intratumoral FOXP3+ regulatory $\mathrm{T}$ cells with improved survival in germinal center-like diffuse large B-cell lymphoma, follicular lymphoma and classical Hodgkin's lymphoma. Haematologica. 2008;93(2):193-200.

102. Chetaille B, Bertucci F, Finetti P, Esterni B, Stamatoullas A, Picquenot JM, et al. Molecular profiling of classical Hodgkin lymphoma tissues uncovers variations in the tumor microenvironment and correlations with EBV infection and outcome. Blood. 2009;113(12):2765-3775.

103. Steidl C, Lee T, Shah SP, Farinha P, Han G, Nayar T, et al. Tumor-associated macrophages and survival in classic Hodgkin’s lymphoma. N Engl J Med. 2010;362(10):875-85.

104. Greaves P, Clear A, Coutinho R, Wilson A, Matthews J, Owen A, et al. Expression of FOXP3, CD68, and CD20 at diagnosis in the microenvironment of classical Hodgkin lymphoma is predictive of outcome. J Clin Oncol. 2013;31(2):256-62.

105. Panico L, Tenneriello V, Ronconi F, Lepore M, Cantore N, Dell'Angelo AC, et al. High CD20+ background cells 
predict a favorable outcome in classical Hodgkin lymphoma and antagonize CD68+ macrophages. Leuk Lymphoma. 2015;56(6):1636-42.

106. Andersen MD, Kamper P, Nielsen PS, Bendix K, RiberHansen R, Steiniche T, et al. Tumour-associated mast cells in classical Hodgkin's lymphoma: correlation with histological subtype, other tumour-infiltrating inflammatory cell subsets and outcome. Eur J Haematol. 2016;96(3):252-9.

107. Guo B, Cen H, Tan X, Ke Q. Meta-analysis of the prognostic and clinical value of tumor-associated macrophages in adult classical Hodgkin lymphoma. BMC Med. 2016;14(1):159.

108. Hollander P, Rostgaard K, Smedby KE, Molin D, Loskog A, de Nully Brown P, et al. An anergic immune signature in the tumor microenvironment of classical Hodgkin lymphoma is associated with inferior outcome. Eur J Haematol. 2018;100(1):88-97.

109. Gholiha AR, Hollander P, Hedstrom G, Sundstrom C, Molin D, Smedby KE, et al. High tumour plasma cell infiltration reflects an important microenvironmental component in classic Hodgkin lymphoma linked to presence of B-symptoms. Br J Haematol. 2019;184(2):192201.

110. Esquela-Kerscher A, Slack FJ. Oncomirs - microRNAs with a role in cancer. Nat Rev Cancer. 2006;6(4):259-69.

111. Arribas AJ, Campos-Martin Y, Gomez-Abad C, Algara P, Sanchez-Beato M, Rodriguez-Pinilla MS, et al. Nodal marginal zone lymphoma: gene expression and miRNA profiling identify diagnostic markers and potential therapeutic targets. Blood. 2012;119(3):e9-21.

112. Wang W, Corrigan-Cummins M, Hudson J, Maric I, Simakova O, Neelapu SS, et al. MicroRNA profiling of follicular lymphoma identifies microRNAs related to cell proliferation and tumor response. Haematologica. 2012;97(4):586-94.

113. Sanchez-Espiridion B, Martin-Moreno AM, Montalban C, Figueroa V, Vega F, Younes A, et al. MicroRNA signatures and treatment response in patients with advanced classical Hodgkin lymphoma. Br J Haematol. 2013;162(3):336-47.

114. Porrata LF, Ristow K, Colgan JP, Habermann TM, Witzig TE, Inwards DJ, et al. Peripheral blood lymphocyte/ monocyte ratio at diagnosis and survival in classical Hodgkin's lymphoma. Haematologica. 2012;97(2):262-9.

115. Koh YW, Kang HJ, Park C, Yoon DH, Kim S, Suh C, et al. Prognostic significance of the ratio of absolute neutrophil count to absolute lymphocyte count in classic Hodgkin lymphoma. Am J Clin Pathol. 2012;138(6):846-54.

116. Juszczynski P, Ouyang J, Monti S, Rodig SJ, Takeyama K, Abramson J, et al. The AP1-dependent secretion of galectin-1 by Reed Sternberg cells fosters immune privilege in classical Hodgkin lymphoma. Proc Natl Acad Sci U S A. 2007;104(32):13134-9.
117. Ouyang J, Plutschow A, Pogge von Strandmann E, Reiners KS, Ponader S, Rabinovich GA, et al. Galectin-1 serum levels reflect tumor burden and adverse clinical features in classical Hodgkin lymphoma. Blood. 2013;121(17):3431-3.

118. Hsi ED, Li H, Nixon AB, Schoder H, Bartlett NL, LeBlanc $\mathrm{M}$, et al. Serum levels of TARC, MDC, IL-10, and soluble CD163 in Hodgkin lymphoma: a SWOG S0816 correlative study. Blood. 2019;133(16):1762-5.

119. Spina V, Bruscaggin A, Cuccaro A, Martini M, Di Trani $\mathrm{M}$, Forestieri G, et al. Circulating tumor DNA reveals genetics, clonal evolution, and residual disease in classical Hodgkin lymphoma. Blood. 2018;131(22):2413-25.

120. Camus V, Viennot M, Lequesne J, Viailly PJ, Bohers E, Bessi L, et al. Targeted genotyping of circulating tumor DNA for classical Hodgkin lymphoma monitoring: a prospective study. Haematologica. 2020;106(1):154-62.

121. Desch AK, Hartung K, Botzen A, Brobeil A, Rummel M, Kurch L, et al. Genotyping circulating tumor DNA of pediatric Hodgkin lymphoma. Leukemia. 2020;34(1):15166.

122. Shi Y, Su H, Song Y, Jiang W, Sun X, Qian W, et al. Circulating tumor DNA predicts response in Chinese patients with relapsed or refractory classical hodgkin lymphoma treated with sintilimab. EBioMedicine. 2020;54:102731.

123. Glaser SL, Lin RJ, Stewart SL, Ambinder RF, Jarrett RF, Brousset $\mathrm{P}$, et al. Epstein-Barr virus-associated Hodgkin's disease: epidemiologic characteristics in international data. Int J Cancer. 1997;70(4):375-82.

124. Kapatai G, Murray P. Contribution of the Epstein Barr virus to the molecular pathogenesis of Hodgkin lymphoma. J Clin Pathol. 2007;60(12):1342-9.

125. Jarrett RF, Gallagher A, Jones DB, Alexander FE, Krajewski AS, Kelsey A, et al. Detection of Epstein-Barr virus genomes in Hodgkin's disease: relation to age. J Clin Pathol. 1991;44(10):844-8.

126. Mancuso S, Carlisi M, Santoro M, Napolitano M, Raso $\mathrm{S}$, Siragusa S. Immunosenescence and lymphomagenesis. Immun Ageing. 2018;15:22.

127. Hjalgrim H, Smedby KE, Rostgaard K, Molin D, Hamilton-Dutoit S, Chang ET, et al. Infectious mononucleosis, childhood social environment, and risk of Hodgkin lymphoma. Cancer Res. 2007;67(5):2382-8.

128. Uccini S, Monardo F, Stoppacciaro A, Gradilone A, Agliano AM, Faggioni A, et al. High frequency of Epstein-Barr virus genome detection in Hodgkin's disease of HIV-positive patients. Int J Cancer. 1990;46(4):581-5.

129. Carbone A, Gloghini A. Epstein Barr Virus-Associated Hodgkin Lymphoma. Cancers (Basel). 2018;10(6):163.

130. Vrzalikova K, Sunmonu T, Reynolds G, Murray P. Contribution of Epstein(-)Barr Virus Latent Proteins to the Pathogenesis of Classical Hodgkin Lymphoma. Pathogens. 2018;7(3):59. 
131. Murray PG, Young LS. An etiological role for the Epstein-Barr virus in the pathogenesis of classical Hodgkin lymphoma. Blood. 2019;134(7):591-6.

132. Henderson S, Rowe M, Gregory C, Croom-Carter D, Wang F, Longnecker R, et al. Induction of bcl-2 expression by Epstein-Barr virus latent membrane protein 1 protects infected B cells from programmed cell death. Cell. 1991;65(7):1107-15.

133. Laherty CD, Hu HM, Opipari AW, Wang F, Dixit VM. The Epstein-Barr virus LMP1 gene product induces A20 zinc finger protein expression by activating nuclear factor kappa B. J Biol Chem. 1992;267(34):24157-60.

134. Eliopoulos AG, Young LS. Activation of the cJun N-terminal kinase (JNK) pathway by the Epstein-Barr virusencoded latent membrane protein 1 (LMP1). Oncogene. 1998;16(13):1731-42.

135. Kilger E, Kieser A, Baumann M, Hammerschmidt W. Epstein-Barr virus-mediated B-cell proliferation is dependent upon latent membrane protein 1 , which simulates an activated CD40 receptor. EMBO J. 1998;17(6):1700-9.

136. Gires O, Kohlhuber F, Kilger E, Baumann M, Kieser A, Kaiser C, et al. Latent membrane protein 1 of EpsteinBarr virus interacts with JAK3 and activates STAT proteins. EMBO J. 1999;18(11):3064-73.

137. Cahir-McFarland ED, Carter K, Rosenwald A, Giltnane JM, Henrickson SE, Staudt LM, et al. Role of NF-kappa $B$ in cell survival and transcription of latent membrane protein 1-expressing or Epstein-Barr virus latency IIIinfected cells. J Virol. 2004;78(8):4108-19.

138. Vockerodt M, Morgan SL, Kuo M, Wei W, Chukwuma MB, Arrand JR, et al. The Epstein-Barr virus oncoprotein, latent membrane protein-1, reprograms germinal centre B cells towards a Hodgkin's Reed-Sternberg-like phenotype. J Pathol. 2008;216(1):83-92.

139. Green MR, Rodig S, Juszczynski P, Ouyang J, Sinha P, O'Donnell E, et al. Constitutive AP-1 activity and EBV infection induce PD-L1 in Hodgkin lymphomas and posttransplant lymphoproliferative disorders: implications for targeted therapy. Clin Cancer Res. 2012;18(6):1611-8.

140. Wood VH, O’Neil JD, Wei W, Stewart SE, Dawson CW, Young LS. Epstein-Barr virus-encoded EBNA1 regulates cellular gene transcription and modulates the STAT1 and TGFbeta signaling pathways. Oncogene. 2007;26(28):4135-47.

141. Baumforth KR, Birgersdotter A, Reynolds GM, Wei W, Kapatai G, Flavell JR, et al. Expression of the EpsteinBarr virus-encoded Epstein-Barr virus nuclear antigen 1 in Hodgkin's lymphoma cells mediates Up-regulation of CCL20 and the migration of regulatory T cells. Am J Pathol. 2008;173(1):195-204.

142. Flavell JR, Baumforth KR, Wood VH, Davies GL, Wei W, Reynolds GM, et al. Down-regulation of the TGF-beta target gene, PTPRK, by the Epstein-Barr virus encoded EBNA1 contributes to the growth and survival of Hodgkin lymphoma cells. Blood. 2008;111(1):292-301.

143. Caldwell RG, Wilson JB, Anderson SJ, Longnecker R. Epstein-Barr virus LMP2A drives B cell development and survival in the absence of normal B cell receptor signals. Immunity. 1998;9(3):405-11.

144. Bechtel D, Kurth J, Unkel C, Kuppers R. Transformation of BCR-deficient germinal-center $\mathrm{B}$ cells by EBV supports a major role of the virus in the pathogenesis of Hodgkin and posttransplantation lymphomas. Blood. 2005;106(13):4345-50.

145. Chaganti S, Bell AI, Pastor NB, Milner AE, Drayson M, Gordon J, et al. Epstein-Barr virus infection in vitro can rescue germinal center B cells with inactivated immunoglobulin genes. Blood. 2005;106(13):4249-52.

146. Oudejans JJ, Jiwa NM, Kummer JA, Horstman A, Vos W, Baak JP, et al. Analysis of major histocompatibility complex class I expression on Reed-Sternberg cells in relation to the cytotoxic T-cell response in Epstein-Barr virus-positive and -negative Hodgkin's disease. Blood. 1996;87(9):3844-51.

147. Ansell SM, Lesokhin AM, Borrello I, Halwani A, Scott EC, Gutierrez M, et al. PD-1 blockade with nivolumab in relapsed or refractory Hodgkin's lymphoma. N Engl J Med. 2015;372(4):311-9.

148. Meti N, Esfahani K, Johnson NA. The Role of Immune Checkpoint Inhibitors in Classical Hodgkin Lymphoma. Cancers (Basel). 2018;10(6):204. 